\title{
Prosthodontic problems and complications associated with osseointegration
}

\author{
Soo-Yeon Shin* \\ Department of Prosthodontics, College of Dentistry, Dankook University, Cheonan, Republic of Korea
}

Edentulous patients with a severely resorbed mandible or maxilla often experience problems with conventional dentures, such as insufficient stability and retention, together with a decrease in chewing ability. Because of the good prognosis of dental implants, these patients can be successfully treated with implant-retained or implant-supported prosthesis. Ideally, a maximum number of implants of maximum length are placed in appropriate surgically prepared sites that are surrounded by a maximum amount of bone of favorable quality. The implants are favorably aligned faciolingually and mesiodistally to enhance optimal prosthodontic design. This article describes the clinical problems and complications encountered when treating a consecutive number of edentulous patients with osseointegrated implant-supported prostheses. (J Dent Rehabil Appl Sci 2015;31(4):349-57)

Key words: implant; osseointegration; prosthodontic complications; prosthodontic problems

\section{서론}

골유착으로 인해 결손치아의 임플란트 수복은 가히 혁 명이라 할 수 있으며, 임플란트만큼 환자의 삶의 질을 향 상시키는 방법 역시 없다. 그러나 골유착 임플란트가 치 아를 대체하는 아주 우수한 치료방법임에도 불구하고 한 계와 합병증이 없지 않으며, 실제 또는 발생가능한 합병 증들을 다룬 문헌들이 많으나, 환자나 치과의사들은 이 러한 합병증에 대해 잘 알지 못하고 있다. 이러한 관점에 서 발생가능한 합병증과 그 빈도에 대해 치과의사들이 명백히 이해하고 환자들에게 기꺼이 전달할 수 있는 것 은 아주 중요하며, 치과의사들은 이러한 정보에 대해 잘 알고 있어야 한다.

임플란트와 연관된 합병증은 크게 생물학적, 기계적 합병증 두 가지로 나누어 볼 수 있으며, 특히 기계적 합 병증은 임플란트와 임플란트 구성요소, 그리고 하부 구

*Correspondence to: Soo-Yeon Shin

Professor, Department of Prosthodontics, College of Dentistry, Dankook University, 119 Dandae-ro, Dongnam-gu, Cheonan, 31116, Republic of Korea Tel: +82-41-550-1973, Fax: +82-41-550-1975, E-mail: syshin@dankook.ac.kr Received: October 19, 2015/Last Revision: October 26, 2015/Accepted: November 11, 2015
조물의 기계적인 손상을 총칭한다. 즉, 임플란트 파절, 유 지요소의 마모나 부식, 유지요소나 하부구조의 파절, 지 대주 파절, 지대주 나사풀림이나 파절, 어태치먼트 나사 풀림 또는 파절, 클립, 러버링, 자성 어태치먼트 O-ring 등의 교환, 임플란트 피개의치의 개상 또는 이장, 임플란 트 피개의치의 파절 등이 포함된다.

여기에서는 임플란트 보철치료와 연관된 기계적 합병증 에 관한 문헌을 살펴보고 몇 가지 증례를 보고하고자 한다.

\section{본론}

\section{1. 임플란트 실패(implant failure)}

보철 수복 이후의 골유착 실패로 인한 임플란트 상실 에 대해서는 많은 전향적, 후향적 연구에서 잘 정리되어 있다. ${ }^{1-3}$ 임플란트 실패는 보통 외과적 합병증으로 분류

Copyright@ 2015 The Korean Academy of Stomatognathic Function and Occlusion. (c) It is identical to Creative Commons Non-Commercial License. 
되고 기능적인 부하이전의 임플란트 실패는 상실된 임 플란트를 추가로 식립하거나 치료계획이나 보철설계를 변경하여 보상할 수 있으므로 보철적인 결과에 최소한 의 영향을 미치는 것으로 보고 있다. 그러나, 임플란트 의 실패는 그 시기와 상관없이, 계획한 보철물의 형태를 변경시키거나 현재의 보철물을 변경하거나 대체해야 할 필요로 인해 직접적으로 보철단계에 영향을 미치게 된 다. 또한 환자와 치과의사 모두에게 대개는 실질적인 시 간이나 비용이 더 많이 필요하게 된다.

Johansson과 Palmquist는 하악에서 3\%, 상악에서 $17 \%$ 의 임플란트 실패를 보고하였으나, $29 \%$ 에서 상실 된 임플란트를 치료받았다는 것을 주목했다. ${ }^{4}$ 그러나 중 요한 것은 임플란트 상실 또는 실패에 대해 자세히 다룬 논문들은 많지만, 그 원인에 대해서는 거의 기술된 바가 없는데, 아마도 대부분의 임플란트 실패의 원인이 명백 하지 않기 때문일 것이다. 즉, 많은 요소들을 실패의 원 인으로 고려해보지만 임플란트 상실의 원인을 과학적인 근거의 단 한가지로 규명할 수는 없다. 초기의 임플란트 상실은 일반적으로 부적절한 외과적 술식이나 식립 부 위의 골질 불량 등으로 인한 임플란트 표면과 골과의 유 착 실패를 원인으로 보는 반면에 후기 임플란트 실패는 많은 잠재적인 원인들과 연관되어 있게 된다.

특히, 보철수복 이후의 임플란트 상실은 급성으로 진 행되는 경우 방사선 사진이나 동요도 테스트를 통해 진 단되더라도 환자의 증상이나 염증성 반응이 없는 경우 가 많기 때문에 미리 발견하기가 쉽지 않다. 이러한 임 플란트 실패의 원인으로는 치태로 인한 임플란트 주위 염, 골질불량으로 인한 부적절한 골지지, 보철물의 적합 도 불량, 교합 부조화, 장축을 벗어난 부하, 캔틸레버 과 부하 등이나, ${ }^{5-8}$ 이러한 원인들 중 그 어떤 것도 임플란트 상실의 가장 중요한 원인이라고 볼 수는 없다(Fig. 1).

\section{2. 보철물의 적합도 불량(prosthesis misfit)}

보철물의 수동적 적합(passive seating)은 골유착을 성 공적으로 유지하는데 반드시 필요하다고 알려져 있다. 이러한 주장에 대한 개념적인 근거는 명백하지만, 과학 적인 뒷받침은 아직까지도 부족하다. 동물실험에서 의 도적으로 부적합을 야기하였으나 예상했던 골소실이나 임플란트 실패는 나타나지 않았다. Jemt와 Book은 5년 간 14 명의 환자를 연구하였는데, 임플란트에 완벽히 수 동적으로 적합되는 보철물은 없었으나, 보철물의 부적 합과 골소실간의 관계를 찾아내지도 못했다. 즉, 부적합 에 대한 일정한 생물학적 내성이 존재하는 것으로 제안 하였다. ${ }^{9}$ 그러면 어느 정도의 부적합이 골소실이나 임상 적인 골유착 실패를 일으키는지에 관한 문제가 남는다. 모든 나사 유지 보철물에서 부적합이 나타나는 것을 인 정하고 일정 수준의 부적합은 불가피하다는 것을 받아 들이는 것은 임플란트 수복에 부주의를 초래할 수도 있 다. 마찬가지로, 문헌을 근거로 부적합이 골조직과 임플 란트 계면간에 해롭지 않다고 가정한다면 또한 합병증 을 초래할 수 있다. 부적합이 골-임플란트 계면에 해로 운지, 어떤 방법으로 부적합의 정도를 측정해야 하는지, 그리고 일단 측정방법이 고안되었다면, 어느 수준까지 임상적으로 부적합을 허용해야 하는지 등에 관해서는 여전히 풀어야 할 문제로 남아 있다. 그러나 확실한 것 은 비록 부적합이 골유착의 안정성에 미치는 영향이 있 든 없든지 간에 부적합은 기계적인 구성성분의 실패를 일으키는 원인인 것으로 보인다. 구성성분의 풀림이나 파절은 여러 원인이 복합적으로 일으키는 것은 명백하 지만, 보철물의 부적합이 나사 파절 같은 합병증에 있어 중요한 역할을 하는 것으로 보아야 한다.
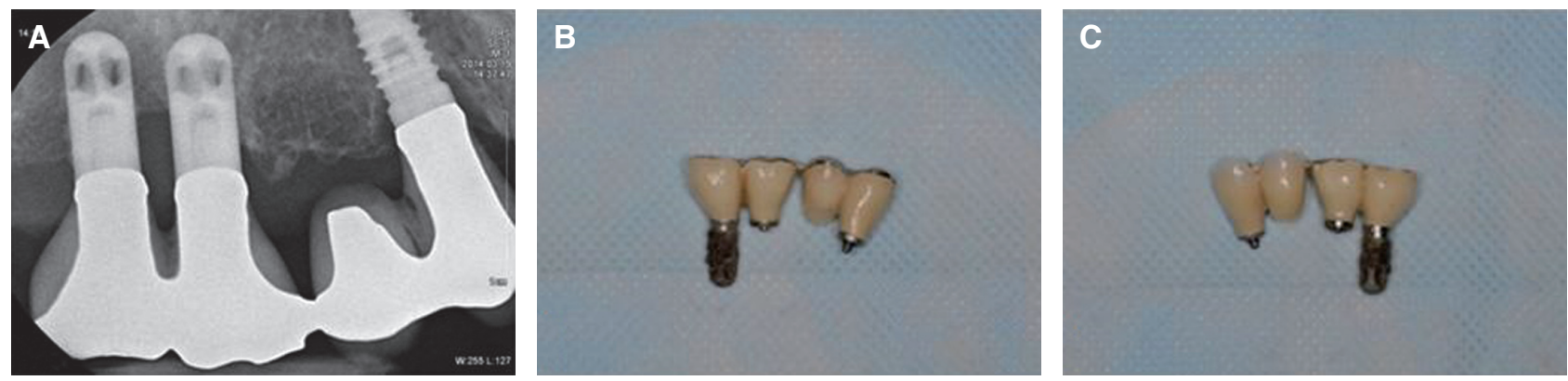

Fig. 1. (A) Implant failure. The causes of late implant failure include plaque-induced peri-implantitis, inadequate support from poor quality bone, misfit of prosthesis, occlusion, nonaxial loading, cantilever overload, and others, (B) Buccal, (C) Ligunal views. 


\section{3. 임플란트 구성요소의 파절(component fracture)}

임플란트, 지대주 나사, 교합면 나사, 보철물의 구조 물, 도재나 레진, 대합악궁의 보철물의 파절은 꾸준히 임플란트 합병증으로 언급되어 왔다. 그 빈도는 논문 마다 다양하나, 주된 합병증인 것으로 보고되고 있다. Adell 등은 15 년간 연구에서 $3.5 \%$ 의 임플란트 파절을 보고하였다. 다른 연구에서는 유사한 기간 동안의 임플 란트 파절 빈도를 $0-16 \%$ 로 다양하게 보고하였다. ${ }^{2,10-12}$ Rangert 등은 임플란트 파절이 많은 환자에서 발생하였 고, 구치부 부분 무치악에서의 단일 또는 두개의 임플란 트 지지 보철물에서 가장 흔히 임플란트 파절이 발생한 다고 보고하였다. 또한 파절된 임플란트의 $59 \%$ 에서는 이미 교합면이나 지대주 나사 풀림이나 파절과 같은 기 계적인 합병증이 있다가 결국 파절된 것을 지적하였다 (Fig. 2). ${ }^{13}$

\section{(1) 임플란트 파절}

임플란트 파절이 골소실보다 먼저 발생하는지 이후에 발생하는지에 관한 문제는 중요하다. Rangert 등은 파절 된 임플란트의 $92 \%$ 에서 임플란트 주위골의 연관된 소 실이 있었다고 보고하였다. ${ }^{13}$ 교합과부하가 임플란트 지 지를 감소시키는 골흡수를 일으키고 결과적으로 파절에 더 민감하게 한다거나, 과부하가 임플란트 고정체의 굴 곡과 변형을 일으키고, 피로, 취약, $\mathrm{crack}$ 의 전파, crack 상부의 동요도 증가 등을 일으켜 임플란트 고정체가 상

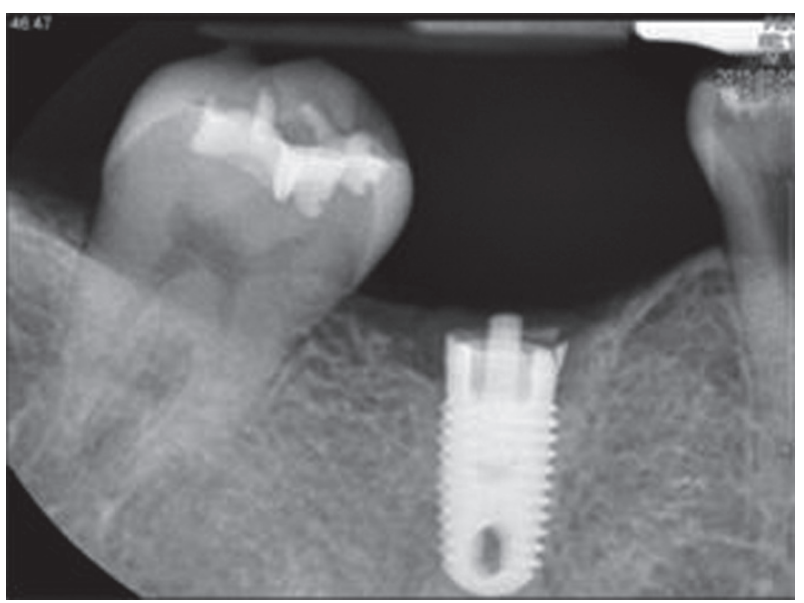

Fig. 2. Single implant prosthesis in the posterior part in partially edentulous situation. After insertion of final prosthesis, prosthesis screw were badly abraded and had to be replaced.
대적으로 움직여 결과적인 골소실을 일으키는 지를 생 각해볼 수 있다. 임상적으로는 이 두가지 실패양상을 구 분하는 것이 중요한데, 방사선 사진상에서 골소실이 보 인다면 과부하 상황이라고 진단할 수 있으므로 과부하 상황을 감소시키고 골지지를 안정화시킴으로써 조정하 고 수정할 수 있다. 반면에, 임플란트 고정체의 crack으 로 인해 임플란트 상부의 움직임의 결과로 인한 골소실 이라면 이미 치명적인 손상이 일어났고 실패는 불가피 하다고 볼 수 있다(Fig. 3).

\section{(2) 임플란트 나사 파절}

임플란트 나사 파절은 흔하게 보고되며, ${ }^{1,4,10,12-15}$ 임플 란트 나사는 가장 작아서 가장 약한 부분으로서 다른 부 분보다 먼저 파절되어 다른 부분의 파절시 어려움을 줄 여주는 것으로 알려져 있다. ${ }^{16}$ Tolman과 Laney는 77명 의 환자에서 89 개의 임플란트 나사 파절을 보고하였 다. ${ }^{12}$ 이것은 이 $26 \%$ 이상이 나사파절을 경험한 것으로 해석할 수 있다. 그러나 실제로는 많은 연구에서 나사파 절을 합병증에 포함시키지 않기 때문에 실제로 그 빈도 를 예측하기가 어려우나, 나사 파절 역시 엄연한 합병증 이며 환자들도 나사 파절이 결코 드문 일이 아니라는 것 을 잘 알아야 한다.

흡수가 심한 악골에서 임플란트에서는 골지지가 부족 하게 되고 이로 인해 과도한 교합력을 받기 쉽다(Fig. 4). 이러한 힘에는 장축방향을 벗어난 중심접촉, 편심위 접 촉, 캔틸레버로 인한 부하, 구성요소나 하부구조물의 적 합도 불량에서 발생되는 내부 응력 등이 포함된다.

쉽게 나사를 교환할 수 있으나, 나사 파절은 너무 많은 유해한 힘이 가해지고 있다는 것을 나타내는 것이며, 이 를 예방하기 위해서는 이상적인 교합관계를 형성하고, 식이조절, 또는 보철물의 설계 변형 등을 시행해야 한다.

\section{(3) 보철물의 구조물 파절}

임플란트나 나사의 파절 이외에도, 보철물의 구조물 이나 아크릴릭 레진의 파절이나 마모, 대합악궁 보철물 의 파절 등이 발생하기도 한다. 이러한 합병증은 재료의 비례한계나 파절강도 이상의 힘이 가해질 때에 관찰된 다. 재료의 오염, 주조 결함, 그리고 합금표면의 부적절 한 처리와 같은 다른 기계적인 실패도 보철적인 문제를 일으킨다(Fig. 5 - 7). 이러한 것들도 명백한 합병증이며 임플란트 자체보다는 보철물의 설계와 더 연관이 있다 고 볼 수 있다. 



Fig. 3. Implant fracture. (A) Implants supported by bone at insertion of final prosthesis, (B, C) After extraction of remaining teeth, occlusal overload caused bone resorption that reduced the support of the implant and resulted in greater susceptibility to fracture, (D) After removal of fractured implants and reimplantion, and (E) After removal of fractured implants and reimplantion.
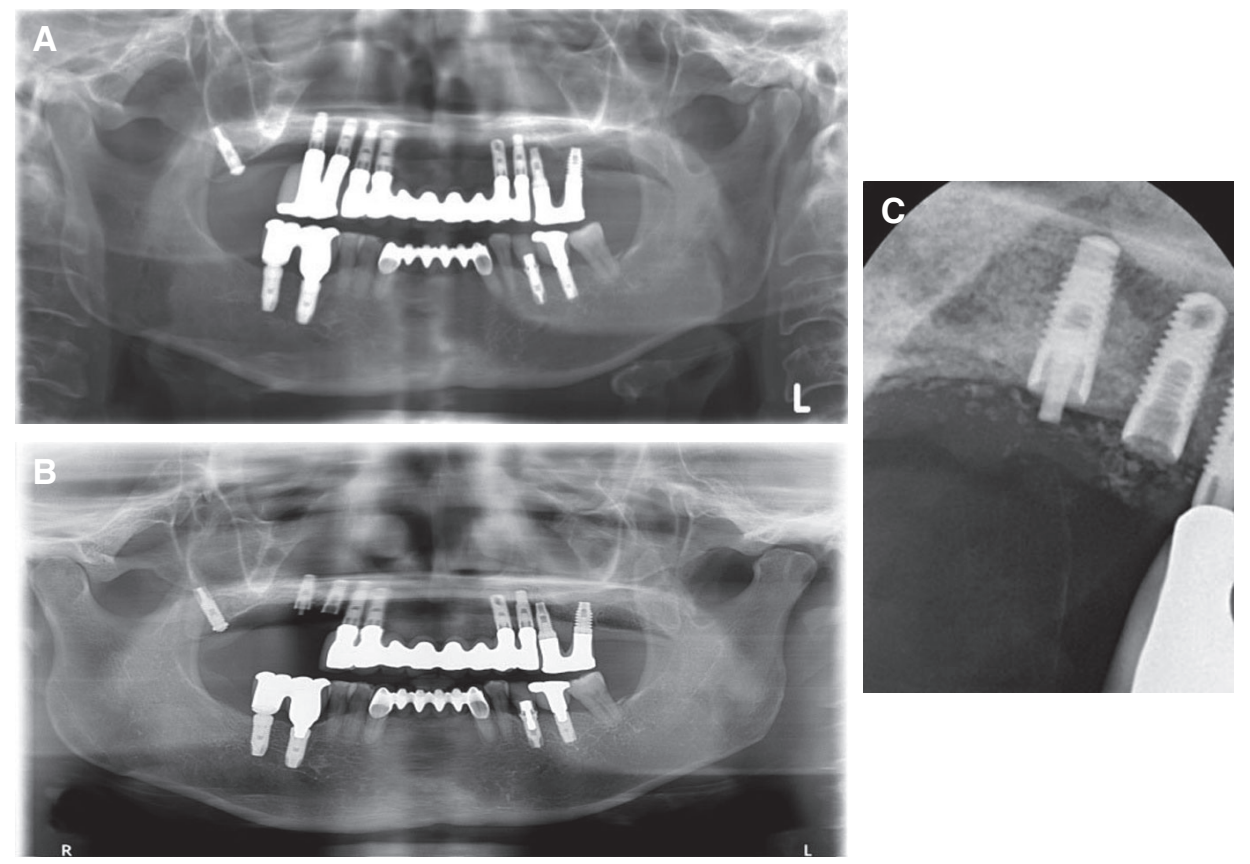

Fig. 4. Screw fracture by deficiency of bone supporting. (A) After insertion of final prosthesis, (B, C) Recurrent prosthesis-retaining screws fractures resulted from combination of factors that included an unfavorable bone support in the severely resorbed maxilla, implants prosthesis may be subjected to excessive masticatory forces. 


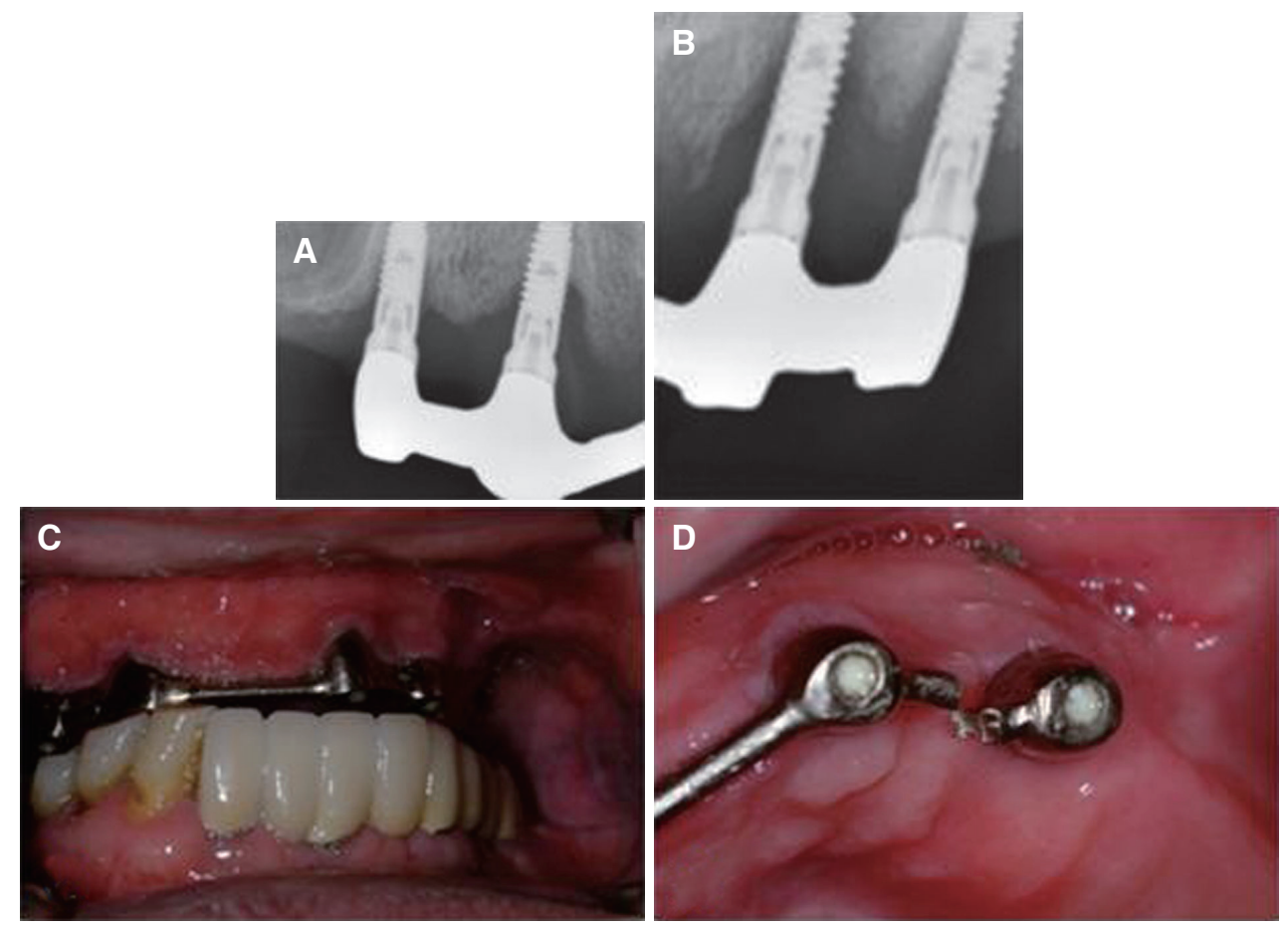

Fig. 5. (A, B) Bone loss around the fixtures were observed. Bar attachment fracture occurred by unfavorable bone support around implants, (C) Buccal view, (D) Occlusal view.
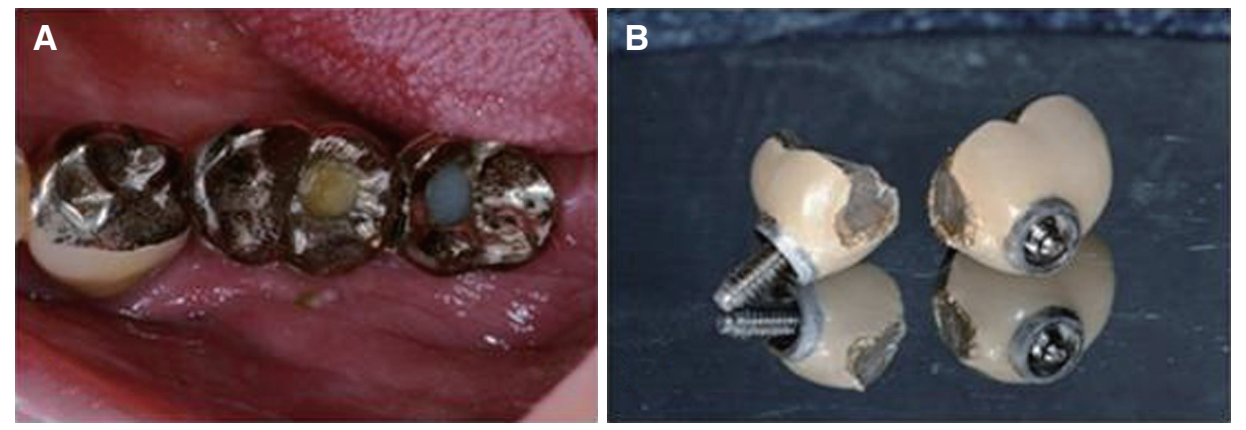

Fig. 6. (A) Patient complained about food impaction between crowns, (B) The implant prosthesis shows failure in solder joint.

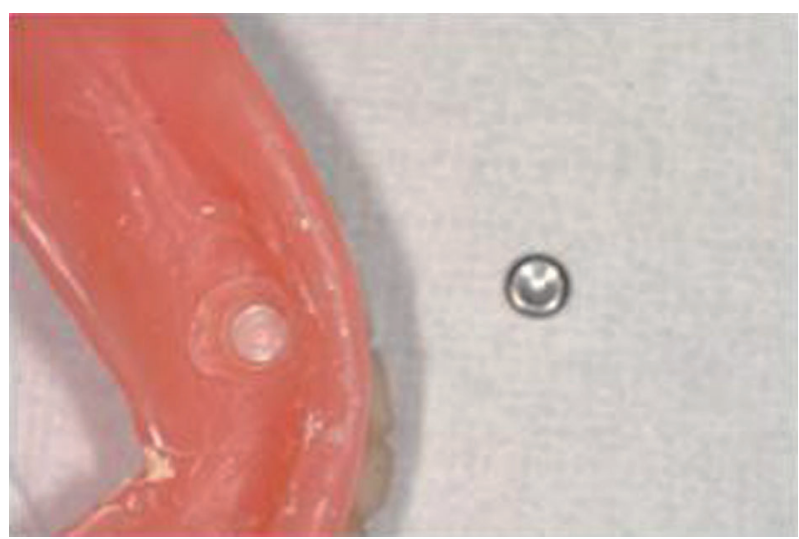

Fig. 7. Magnetic attachment failure of implant overdenture.

\section{4. 나사 풀림(screw loosening)}

나사 풀림의 빈도는 문헌상에서 다양하게 보고되고 있어 정확히 알기 어려운데, 몇몇 연구에서 언급하고는 있으나 대부분은 나사 풀림을 합병증에서 제외하거나 다루지 않거나, 나파 파절과 나사 풀림을 같은 것으로 보기 때문이다. ${ }^{1-4,11,13-15,17}$ Naert 등은 $5 \%$ 의 나사 풀림을 보고하였고, ${ }^{10} \mathrm{Jemt}$ 는 보철물 장착 후 첫 번째 검사에서 단지 $69.3 \%$ 에서만 나사가 안정적이었다고 보고하기도 하였다. ${ }^{18}$ 어떤 저자들은 나사 풀림은 합병증이지만 "설 계상 풀릴 수 밖에 없는” 것으로 보기도 하였지만, 환자 
와 치과의사 모두에게 불편하고 자주 발생할 경우 경제 적으로 부담이 되며, 다른 구성 요소의 실패가 임박했다 는 표시가 되기도 하며, 또한 반복적인 나사 풀림에 관 한 보고도 드물지 않다. ${ }^{12}$ 그래서 통상적으로 5 년마다 한 번씩 나사를 다시 조여주는 것을 추천하기도 하지만, ${ }^{19}$ 그보다 더 자주 점검하는 것이 바람직하며 나사 풀림이 반복된다면 교체도 고려해야 한다(Fig. 8).

\section{5. 부적절한 식립 설계 및 치료계획}

보철 단계에서의 문제를 최소화 하기 위해서는 다양 한 요소에 대해 주의를 기울여야 기계적인 합병증을 방 지할 수 있다. 임플란트 보철수복과 연관된 가장 흔한 문제들은 나사 풀림이나 파절이며, 이러한 합병증은 구 강내 힘의 정도와 방향, 그리고 구성 요소 응력의 한계 때문에 주로 발생한다. ${ }^{20,21}$ 그 밖에, 술자의 오류, 그리
고 온도변화도 또한 나사풀림의 원인이 될 수 있다. 게 다가, 치조제의 흡수량, 임플란트의 수와 길이, 대합악 궁의 상태, 임플란트의 식립각도, 그리고 parafunctional habits 등도 이러한 합병증에 대한 민감도를 높인다. ${ }^{22}$ 흡수가 심한 치조제에서는 임플란트 보철물이 과도한 교합력을 받게 되며, 이러한 힘에는 중심교합 장축을 벗 어나거나, 편심위 접촉, 캔틸레버로 인한 부하 등도 포 함된다. 또한 경사지게 식립된 임플란트에서는 교합력 은 나사가 견딜 수 있는 응력 이상의 힘을 발생시킨다. 그러므로 이러한 보철적인 문제점들을 예방하고 최소화 하기 위해서는 보철물 설계시 캔틸레버 길이는 가능한 줄이고, 교합 설계시 비작업측 접촉은 제거해야 하며 중 심교합접촉은 장축 중심으로 유도하고, 보철물 제작시 보철물의 적합도를 향상시키도록 노력하고 구성요소들 은 제조자의 지시대로 토크를 가해야 한다(Fig. 9).
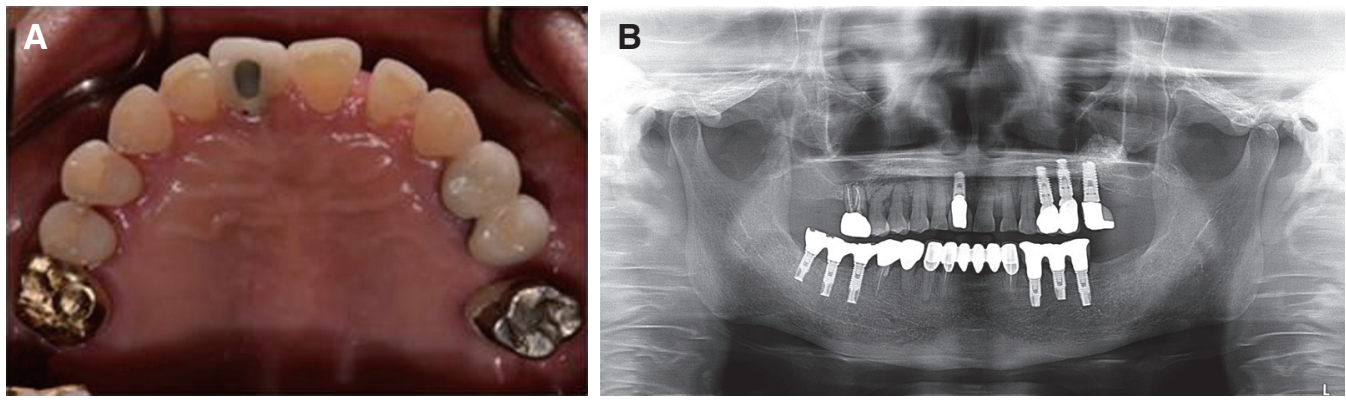

Fig. 8. Prosthesis-retaining screw loosening. Rotated crown was observed on occlusal view (A) and panoramic view (B).
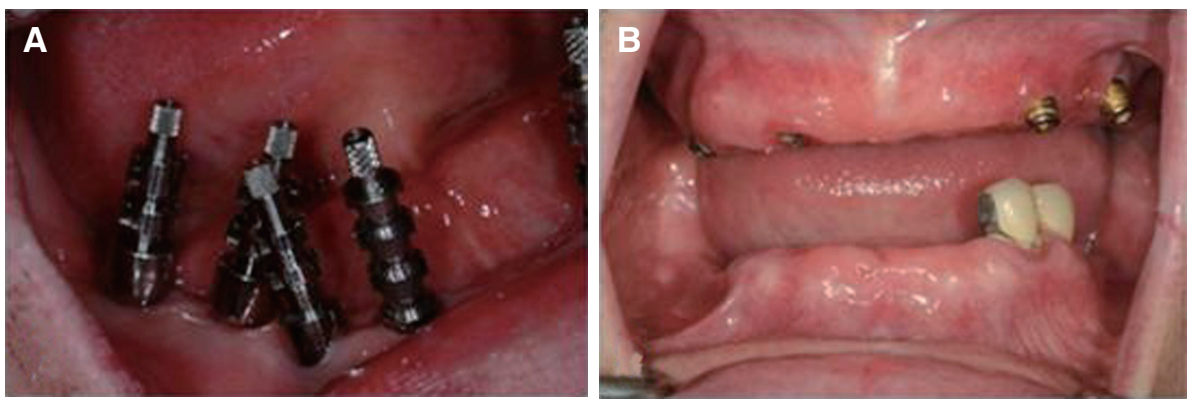

Fig. 9. Improper implant placement can result in framework design that compromises esthetics and distribution of force on implants. (A) Fixtures placed too close together may prevent the active use of a fixture in the final prosthesis design, (B) Fixtures placed in buccal version preclude generation of occlusal forces in the long axis of the fixture. 


\section{결론}

임플란트는 지난 수십년간 기존 방식의 보철물을 대 체할 만한 아주 성공적인 치료방법이었음에 틀림없으 나, 유지관리가 상당부분 뒷받침되어야 하며, 사실상 의 치관리보다도 더 많은 시간과 노력이 필요하다. 또한 그 에 따른 문제점과 합병증의 위험이 없지 않으나, 이에 관한 객관적인 보고가 부족하고 자료에 대한 분석이 정 확하지 않아 그 발생 빈도와 정도, 다양성에 대해 알기 어렵다. 또한 많은 기술적인 합병증의 원인들이 아주 명 확하지는 않기 때문에 비용과 치료의 복잡성에 대해 중 요하게 생각해야 한다. 그러므로 임플란트를 시술하는 치과의사들은 반드시 잠재적인 합병증의 위험에 대해 알고 있어야 하며, 임플란트 치료를 받으려는 환자들에 게도 알려야 한다. 그리고 무엇보다도 철저한 진단과 치 료계획과 정기적인 검진의 중요성에 대해 다시 한번 기 억해야 한다.

\section{Acknowledgements}

본 연구는 2015년 단국대학교 교내연구비 지원으로 연구되었음.

\section{ORCID}

Soo-Yeon Shin http://orcid.org/0000-0001-6160-7277

\section{References}

1. Adell R, Lekholm U, Rockler B, Brånemark PI. A 15-year study of osseointegrated implants in the treatment of the edentulous jaw. Int J Oral Surg 1981;10:387-416.

2. Albrektsson T, Dahl E, Enbom L, Engevall S, Engquist B, Eriksson AR, Feldmann G, Freiberg N, Glantz PO, Kjellman O, Kristersson L, Kvint S, Kondell PA, Palmquist J, Werndahl L, Astrand P. Osseointegrated oral implants. A Swedish multicenter study of 8139 consecutively inserted Nobelpharma implants. J Periodontol 1988;59:287-96.

3. Albrektsson T. A multicenter report on osseointegrated oral implants. J Prosthet Dent 1988;60:7584.
4. Johansson G, Palmqvist S. Complications, supplementary treatment, and maintenance in edentulous arches with implant-supported fixed prostheses. Int J Prosthodont 1990;3:89-92.

5. Lindquist LW, Rockler B, Carlsson GE. Bone resorption around fixtures in edentulous patients treated with mandibular fixed tissue-integrated prostheses. J Prosthet Dent 1988;59:59-63.

6. Ogiso M, Tabata T, Kuo PT, Borgese D. A histologic comparison of the functional loading capacity of an occluded dense apatite implant and the natural dentition. J Prosthet Dent 1994;71:581-8.

7. Isidor F. Loss of osseointegration caused by occlusal load of oral implants. A clinical and radiographic study in monkeys. Clin Oral Implants Res 1996;7:143-52.

8. Isidor F. Histologic evaluation of peri-implant bone at implants subjected to occlusal overload or plaque accumulation. Clin Oral Implants Res 1997;8:1-9.

9. Jemt T, Book K. Prosthesis misfit and marginal bone loss in edentulous implant patients. Int J Oral Maxillofac Implants 1996;11:620-5.

10. Naert I, Quirynen M, van Steenberghe D, Darius P. A study of 589 consecutive implants supporting complete fixed prostheses. Part II: prosthetic aspects. J Prosthet Dent 1992;68:949-56.

11. Adell R, Eriksson B, Lekholm U, Brånemark PI, Jemt T. Long-term followup study of osseointegrated implants in the treatment of totally edentulous jaws. Int J Oral Maxillofac Implants 1990;5: 347-59.

12. Tolman DE, Laney WR. Tissue-integrated prosthesis complications. Int J Oral Maxillofac Implants 1992; 7:477-84.

13. Rangert B, Krogh PH, Langer B, Van Roekel N. Bending overload and implant fracture: a retrospective clinical analysis. Int J Oral Maxillofac Implants 1995;10:326-34.

14. Zarb GA, Schmitt A. The longitudinal clinical effectiveness of osseointegrated dental implants: the Toronto study. Part III: problems and complications encountered. J Prosthet Dent 1990;64:185-94.

15. Walton JN, MacEntee MI. Problems with prostheses on implants: a retrospective study. J Prosthet Dent 1994;71:283-8. 
16. Worthington P, Bolender CL, Taylor TD. The Swedish system of osseointegrated implants: problems and complications encountered during a 4-year trial period. Int J Oral Maxillofac Implants 1987;2:77-84.

17. Cox JF, Zarb GA. The longitudinal clinical efficacy of osseointegrated dental implants: a 3-year report. Int J Oral Maxillofac Implants 1987;2:91-100.

18. Jemt T. Failures and complications in 391 consecutively inserted fixed prostheses supported by Brånemark implants in edentulous jaws: a study of treatment from the time of prosthesis placement to the first annual checkup. Int J Oral Maxillofac Implants 1991;6:270-6.
19. Kallus T, Bessing C. Loose gold screws frequently occur in full-arch fixed prostheses supported by osseointegrated implants after 5 years. Int J Oral Maxillofac Implants 1994;9:169-78.

20. Binon PP. Implants and components: entering the new millennium. Int J Oral Maxillofac Implants 2000;15:76-94.

21. Brunski JB, Puleo DA, Nanci A. Biomaterials and biomechanics of oral and maxillofacial implants: current status and future developments. Int J Oral Maxillofac Implants 2000;15:15-46.

22. Sones AD. Complications with osseointegrated implants. J Prosthet Dent 1989;62:581-585. 


\section{임플란트 보철물의 임상적 합병증에 관한 고찰}

\section{신수연*}

단국대학교 치과대학 치과보철학교실

무치악 환자에 있어서 골유착 임플란트는 통상의 다른 보철수복방법과 비교했을 때, 기능적으로나 환자의 만족도 면 에 있어서 아주 좋은 결과를 보이며, 삶의 질 향상에도 가장 우수한 것으로 알려져 있다. 골질이 양호하고 골량이 충분 한 부위에 외과적으로 많은 수의 임플란트를 적절히 식립하여, 최상의 임플란트 보철물 설계가 가능하게 배열되는 것 이 바람직하나, 아직까지는 환자와 치과의사 모두에게 합병증과 여러 문제들이 한계로 남아 있다. 골유착에 관한 보철 적인 문제, 즉 임플란트 실패, 보철물의 부적합, 임플란트 구성요소의 파절, 그리고 나사 풀림 등 합병증에 관해 분석하 고 그에 관한 증례를 보고하고자 한다.

(구강회복응용과학지 2015;31 (4):349-57)

주요어: 임플란트; 골유착; 보철적 합병증; 보철적 문제 